\title{
TERRORISM - THE DARK SIDE OF DEMOGRAPHIC DIVIDEND. A CASE STUDY OF PAKISTAN
}

\section{EXPLORING THE TOPIC}

Demographic dividend is termed as the period of exponential population growth in a country resulting in youth bulge during 15-20 year period. In other words demographic dividend could be considered as a corollary to demographic transition. Because of the shift in demographics with respect to mean age over a period of time more people fall under the age bracket of 15-64 than below 15 and above 64. Simply put younger the population higher the chances of economic activity because of the abundance of human resource.

David Bloom and Jeffery J Williamson, two development economists, coined the term. The term gained currency after Bloom and Williamson studied the East Asian growth model and analyzed the success of South East Asian countries (aka Asian Tigers: Malaysia, Indonesia, Singapore, Taiwan, Thailand, South Korea and Vietnam) and attributed it to these countries' carefully managed population policies to yield demographic dividend. They identified the changing age-structure for accounting two-fifth of East Asia's economic miracle.

The phenomenon of demographic dividend does not take place suddenly. Rather it is transited first from high birth and death rates to low birth and death rates as a country evolves from agrarian to industrial. In certain cases the demographic dividend is the outcome of the demographic transition which then allows a country to grow rapidly because of the high working age population. This also increases per capita income and savings (Can Pakistan, 2012). States, in order to reap its benefits tend to plan in advance and at the time of its occurrence utilize the available human resources for generating economic development and progress.

According to the United Nations Population Fund: "The demographic dividend is the economic growth potential that can result from shifts in population's age structure, mainly when the share of the working-age population (15-64) is larger than the non-working-age share of the population (15 and younger and 65 and older)" (Demographic Dividend, 2008).

Simply put, demographic dividend is the result of high birth rate for a certain period of time. It shifts the demographics of a country resulting in more young people in that society than the older ones i.e. it lessens the number of dependents and allowing the society to reap the benefits of a younger, healthier, and educated generation which could fasten the economic growth rate of the state. 
Demographic dividend has certain advantages. In recent past countries such as Ireland, South Korea, Thailand, and India have been able to reap the benefits of demographic dividend for galvanizing economic activity. According to recent research, India because of its educational and training infrastructure for both vocational and other means of trainings would become the largest exporter of labor by 2020 .

On the other hand, if unprepared to reap its benefits with advanced planning, the demographic dividend may cause catastrophic effects for a country. Scores of Least Developed Countries (LDC) with an overwhelmingly young population could face humongous problems of coping with their youth bulge. In contrast to reaping its benefits hitherto few countries have been able to capitalize on demographic dividend. Presence of a huge cluster of an unskilled youth with not many employment opportunities may fall easy prey to criminal mafias and cartels; and terrorist organizations. Yemen, Egypt, Iraq, Syria, Pakistan and Libya may be cited as recent examples of countries experiencing youth bulges.

Demographic dividend usually creates positive impact on a state experiencing it. Demographic dividend is the result of demographic transition which if not properly taken care of could yield negative results on the same country. The negative impact may occur terrorist groups tend to recruit more people perhaps because of youth bulge and depleting resources. Demographic dividend provides an opportunity for both states and non-state actors to reap the benefits. Terrorism on the other hand is premeditated, deliberate, and systematically planned tactics to coerce the government and instill fear in the minds of public to attain certain desired politico-religious objectives by violent non-state actors. Like any other enterprise leaders and ideologues of terrorist organizations look for potential recruits as the business of terrorism essentially requires human resources in abundance to unleash waves of terrorist attacks. The occurrence of demographic dividend in any country could be as useful for a terrorist as for the government. If government fails to reap the benefits of demographic dividend the terrorist organizations may have their chances of benefitting from the phenomenon. The case study of Pakistan, a country experiencing demographic dividend, may provide us an insight in such scenario.

\section{INTRODUCTORY REMARKS}

Demographic explosion has swept across many third world countries. The world population touched the first billion mark in 1850 and in next 165 years has swelled up to 7 billion (Roser n.d.) the biggest ever surge mainly because of exponential advancement in medical science. The sudden change in world demographics has forced the demographers to study and analyze the population transitions. Besides demographers the development economists are also interested in studying the phenomenon to use for their own advantages. The links between demographic transition and the resultant demographic dividends has now become a subject of keen interest for not only economists but also policy makers. Some visionary policy makers have been able to use the transition for the changing the development course of their nations. Thailand, Ireland and South Korea could be bracketed in that category. They were successful in timely policy 
measures which consequently brought sound growth and prosperity to their respective countries.

Fortunately, Pakistan is considered to be one of states experiencing the phenomenon of demographic dividend. A largely young population with dependents on the borderline may allow Pakistan economy to experience a rapid growth rate. Though, not one of the BRICS nations, Pakistan is part of Next-11, group of countries with great economic potential because of their human resources (The $N-11,2007$ ).

Reaping the benefits of demographic dividend would be in the best interest of Pakistan. An economically vibrant Pakistan may be the only way-forward to dilute many of the Pakistan's problems. Currently the country is facing huge economic turmoil, with a cash-starved economy, slow GDP growth rate, energy crisis, and $\$ 65$ billion (Pakistan's external, 2014) external debts are some of the major economic woes of Pakistan. Coping with the demographic transition and demographic dividend could pave the way for robust economic growth. Pakistan's population is increasing at a dangerous rate. With an average family size of 7 the country is expected to grow at a rate of around 1.5 to 2 percent reaching 309 million by 2050 (World Population Prospects, 2015). According to World Bank data poverty headcount ratio at $\$ 1.90$ a day (2011 PPP) is around 8.3 percent. However, this ratio is 22 percent based on national poverty line. Although poverty ratios have come down significantly in recent years, large numbers still live around the poverty line and are vulnerable. Notably, the income share held by the lowest ten percent of the population is mere four percent, whereas as the highest ten percent hold around 26 percent of the income. This reflects persistence of inequality that is reflected in the Gini index of 30 .

In economics demographic dividend refers to a steady growth of young population over a span of time because of decline in mortality rates due to increasingly better health care facilities. The phenomenon leads to a youth bulge in the overall demographics of the particular country experiencing the period what refers to as demographic dividend.

The shift in population's age structure paves the way for economic growth potential because of the changed share of the working age population. In most case the working age population (15-64) overtakes the non-working age share of the population.

Pakistan, the sixth most populous country in the world, is experiencing demographic dividend. The phenomenon could bring in immense advantages to the country. Pakistan is also experiencing a variety of terrorist movements in the country. Islamist terrorist groups have cost the country enormous human and material losses in last 14 years. Perhaps Pakistan is the only country which is simultaneously experiencing both terrorism and demographic dividend.

The paper intends to study and analyze the effects of demographic transition on terrorism and to prove that Islamist terrorist organizations in Pakistan could take advantage of the demographic transition if state fails to reap the benefits of the demographic dividend. The study would be an endeavor to find the relationship between rise of Islamist terrorism in Pakistan and demographic dividend and analyze and assess future course of terrorism amid demographic dividend:

Q1 Why Pakistan has not been able to reap the benefits of demographic dividend and could this disadvantageous situation benefit the Islamist terrorist groups in country? 
Q2 What are the options to convert population explosion to demographic dividend and avoid terrorist groups to take advantage of it?

The study analyzes the phenomenon of demographic dividend in Pakistan by employing qualitative, analytical and descriptive methods. The study relies on both primary and secondary sources. ${ }^{1}$

The study is important to examine the phenomenon of demographic dividend. Keeping in view of the experiences of Thailand, South Korea and Ireland, Pakistan may also reap the benefits of demographic dividend. Research in this area is vital to explore possible ways and means to explore, analyze, and evaluate scenarios for taking advantage. The situation cannot be avoided as available data has already started to showcase the scenario. Therefore it is imperative to study the phenomenon on the basis of available data and taking, studying other countries' strategies to deal with it and finally replicating the scenarios with calibrations. There may be horrific situations if demographic dividend is not handled with care. The demographic transition provides opportunities for nations to fast track progress. Demographic dividend is indeed part of the process and policy makers may take advantage of it.

\section{DEMOGRAPHICS OF PAKISTAN}

Pakistan the sixth most populous country in the world currently and according to the World Bank has an annual population growth rate of 2.1 percent in 2014. At this growth rate the population of Pakistan is expected to swell up to 250 million by 2025 from the current 185 million, and to 344 million in 2050 (Projected Populations, 2012) to become the fourth most populous country. This immense demographic challenge may hinder Pakistan's economic growth potential if proper plans are not made to counter the situation.

On one hand the looming crisis showcases dwindling resources and an increasing population at an alarming rate while the other side of the picture appears bright. The demographic transition may be utilized by Pakistan's economic managers and planners. The demographic dividend which represents a young, independent and skilled labor force could be used for mobilizing the engines of economic growth. Population density is likely to increase from 186 persons per square kilometer to 334 by 2030 (Burki, 2011). In next 10 years more than 50\% Pakistanis would be residing in urban areas and by then the total population may grow up to 226 million, meaning 113 million people living in urban centers of Pakistan (ibidem). The United Nations' Population division has also given details about Pakistan's population scenarios. According to UN estimates:

1 Studying the phenomenon of demographic dividend in Pakistan is indeed complex. The available data on the subject matter, considering the its significance with respect to Pakistan's demographic, is not much. Dur-e-Nayab explicitly wrote over the subject and in her paper Demographic Dividend or Demographic Threat in Pakistan she discussed issues related to the systemic problems in Pakistan's educational system which may allow serious impediments in reaping the benefits of demographic dividend. Asad Kamal previously analyzed the effects of demographic dividend and its impact on the development of FATA. 
- population of Pakistan will rise to 335 million by 2050;

- at least 60 million people are expected to be added in next 15 years;

- if the fertility rate, which is expected to fall, does not fall the current fertility rate would likely to surge Pakistan's population to 450 million;

- presently two-third of Pakistanis is under 30 years of age;

- by 2050 the median age of Pakistani is expected to be 33 (Kugelman, 2011).

Table 1

Age Structures in Pakistani Population (2014)

\begin{tabular}{|l|c|c|c|}
\hline \multicolumn{1}{|c|}{ Age Structures } & Total \% & Male & Female \\
\hline 0-14 years & 33.3 & $33,595,949$ & $31,797,766$ \\
\hline 15-24 years & 21.55 & $21,803,617$ & $20,463,184$ \\
\hline 25-54 years & 35.7 & $36,390,119$ & $33,632,395$ \\
\hline 55-64 years & 5.1 & $5,008,681$ & $5,041,434$ \\
\hline 65 and above & 4.3 & $3,951,190$ & $4,490,045$ \\
\hline
\end{tabular}

Total Population: 196,174,380 (July 2014 est.)

Source: CIA World Factbook, Pakistan Demographics, 2014.

\section{OCCURRENCEOF DEMOGRAPHIC DIVIDEND}

Pakistan started experiencing demographic dividend in 1990 and expectedly the life span of demographic dividend in Pakistan may last up till 2050. Pakistan could benefit from its demographic transition and earn demographic dividend. The phenomenon is already occurring in Pakistan because the country fulfills the characteristics required for happening. The abundant supply of labor, decline in mortality, decline in fertility and resulting human capital apparently suffice the requirements for demographic dividend to take its roots in Pakistan. The population is expected to grow and overall population mass appears increasing till 2050. The population growth rate is expected to decline from current $2 \%$ in 2015 to 0.78 percent in 2050 (Durr-e-Nayyab, 2008). The working age population (15-64 yrs.), which is around 60 percent currently, is expected to reach around 68 percent of the population by 2045 (ibidem).

Pakistan is passing through its demographic transition and $50 \%$ of the population is below 20 years, whereas $60 \%$ are under 30 years of age. The so-called youth bulge, which is responsible for the surge in the country's work force, is expected to grow percent annually (Bokhari, 2011). According to the estimates of Planning Commission of Pakistan, Pakistan's economy has to grow at a rate of $7 \%$ to absorb the additional labor force, which is growing at a rate of 3 percent annually (Pakistan Economic Survey, 2012). In his study on demographic dividend in Pakistan R. Amjad considers weak participation of women in workforce, low reallocation of labor in value added sectors, low levels of education, and poor youth profile as impediments for reaping demographic dividend in Pakistan (Amjad, 2013). 
Demographic dividend, theoretically, is the difference in the growth rates of working age population and total population. The dividend is said to occur if this difference is positive. According to projected estimates, the dividend is expected to persist till 2050 , providing Pakistan with a huge window of opportunity. The basic premise of the demographic dividend is that the young $(<15$ years old) and old ( $>64$ years old) tend to consume more than they produce. In contrast, the working age population (15-64 years) is expected to contribute more to output and savings.

Durr-e-Nayab (2008) points out that demographic dividend can be reaped through systematic complementarities between labor supply, savings, and human capital. As a consequence of demographic transition, there is an increase in the supply of labor as more people enter the bracket of productive years. Moreover, there is a tendency of more females entering the labor force as fertility rates decline. However, this increase in labor supply is a benefit only if it is adequately trained and employed so that it can contribute positively to GDP. Importantly, the labor force participation rate is only $56 \%$ in Pakistan ( $25 \%$ for females, $86 \%$ for males). Notably, as a consequence of demographic transition labor force participation rate in females has increased from $13 \%$ in 1990 to around $25 \%$ in 2014. Even with this relatively low rate of labor force participation, unemployment rate in Pakistan is around 5\% (female: 9\%, male: 4\%). Labor force in Pakistan has swelled from 31 million 1990 to 64 million in 2014. According to World Bank data for Pakistan (in year 2008) labor force with primary education is only 15 to $16 \%$ underscoring the mediocre quality of labor (World Bank data). Dividends of the labor supply, however, can only be reaped if complementary policies are in place that can enhance the quality of labor force as well as provide economic growth that can absorb the supply of this labor.

Demographic transition is expected to encourage savings, due primarily to low dependency ratios, improving a country's capacity to invest and propel economic growth. Gross domestic savings (as a percentage of GDP) have, however, remained low and less than $10 \%$ over the past several years (around $7.5 \%$ of GDP in 2014). This savings percentage is more than $30 \%$ in East Asian economies of Korea, Thailand, and Malaysia (World Bank data). Importantly, savings are also influenced by several factors other than the demographic transition like the quality of banking system, interest rates, investment climate, and inflation expectations. Arguably, these complementary factors are not favorable to encourage savings rates in Pakistan.

Investment in human capital is influenced by demographic transition. It is agued that demographic transition enhances the premium on education level that in turn increases the productivity of labor force. However, both the quantity and quality of education are important. In Pakistan, for example, literacy rate among youth male (ages $15-24$ yrs.) is approximately $80 \%$. However, it is difficult to assess the quality of education. Government expenditure on education (as a percentage of GDP), which arguably is a determinant of the quality of education, is quite low at $2.49 \%$ of GDP for Pakistan when compared to around 5\% in emerging economies of East Asia (5.9\% in Malaysia, $4.9 \%$ in Thailand, and $4.6 \%$ in Korea).

It is evident, therefore, that the necessary combination of labor supply, savings, and human capital that is necessary to transform the dividend into an opportunity is lacking in Pakistan. However, a conscious policy framework can still enable the country to benefit from this opportunity. 


\section{LEARNING FROM THE EXPERIENCED NATIONS}

It is estimated that every country gets once-in-a-lifetime opportunity of experiencing demographic dividend. Pakistan may learn from Ireland, and Thailand, two countries that successfully managed to reap the benefits of demographic benefits during 1970s and 1980s. The primary focus for earning demographic dividend is on overall literacy level, skill development and women's contribution on the labor side. Without women empowerment in the form of high literacy rate and an equal opportunity job market, reaping the demographic dividend is not possible.

India, Pakistan's bęte noir is also experiencing demographic dividend. Indian policy makers have been worried for a while because of a compelling pressure to reap the benefits of it. By 2026 youth (15-59) would comprise $64 \%$ of India's population leaving only 13\% above 60 years of age (Reaping India's, 2010: 7). Currently India has 605 million people below 25 years of age, and among these 225 million are in the age bracket of 10-19. According to estimates by International Labor Organization (ILO) while the rest of the developed world is having considerable ageing population by 220 India will have a ready work force of 116 million (20-24) by 2020 in comparison to China's 94 million (Tharoor, 2014). The disadvantaged situation India is being faced is the very small size of its formally skilled workforce which is only $2 \%$ of the total labor force in comparison to South Korea's 96\%, Japan's 80\%, Germany's 75\% and United Kingdom's 68\% (Reaping India's, 2010: 9). In this situation India would be having the advantage of median age of 29 years by 2020 in comparison to 47 in Japan, 46 in Europe and 40 in USA. Despite having a disadvantage of skilled labor force the labor force is expected to grow by $32 \%$ whereas in China figure will decline by $5 \%$ (Tharoor, 2014). Dealing with this upcoming situation would be an uphill task as the figures could work like a double-edged sword. For reaping the benefits of demographic dividend India will have to generate an educated female work force with equal employment opportunities. Currently $60 \%$ of women graduates in India are unemployed, with one of the lowest female unemployment rate alongside Pakistan and Middle Eastern countries. $92 \%$ of India's work force (470 million) is informally skilled (Nagarajan, 2014). With such prevailing conditions India's dream of earning demographic dividend could not come true. Without a skilled labor force the window of opportunity could turn into a disaster. Despite having these grave difficulties the Indian economy is growing at a reasonably good rate. Currently India is the $9^{\text {th }}$ largest economy, with a GDP growth rate of 7.4\% in 2014-2015 fiscal year (2010: 10.3\%, 2011: 6.6\%, 2012: 5.1\%, 2013: 6.9\%) (GDP Growth, 2015), allowing the country to reap its demographic dividend at a slow rate. According to International Monetary Fund (IMF)'s projections the demographic dividend could add 2\% GDP growth rate per annum (Aiyar, Mody, 2011).

South Korea is quoted as a country, which in true sense reaped the benefits of demographic dividend. The demographic transition started after the Korean War (1950-1953) and South Korean policy makers' well-times policies led the nation to earn demographic dividend. South Korea is now the $13^{\text {th }}$ largest economy in the world in terms of nominal GDP ( $\$ 1.4$ trillion); it is the $5^{\text {th }}$ largest exporter and $7^{\text {th }}$ largest importer. South Korea was placed among the countries termed as Asian Tigers (Malaysia, Indonesia, Singapore, Thailand, Taiwan and Hong Kong). The South Korean economy grew at 
a rate of $6.7 \%$ between $1960-1990$ (Gribble, 2012). The South Koreans earned their demographic dividend mainly because of investing in reproductive health program, focus on education, planning of infrastructural development projects keeping in view of demographics. Population policies were also framed to address population growth rate issues and increasing the size of manufacturing sector. Because of the policy initiatives the fertility rate began to drop from 5.4 children to 2.9 children per women by 1975 . For comprehensively reaping the benefits of demographic dividend the policy makers focused on education. The 54\% enrolment rate between 1950-1960 was increased up to $97 \%$ in 1990, which gave rise to a 'production-oriented' population for achieving economic development (ibidem). The South Korean government also focused on comprehensive economic planning. The pre-war economy was primarily based on farming and fishing. The industrial sector was almost non-existent. Rural construction program was initiated for the uplifting the standard of living and economic activities in the countryside. The rural planning lessened the burden of mass migration to urban centers. The Vietnam War (1964-1975) provided an opportunity for Korean economy to grow which Korean public sector economist capitalized on. Nascent South Korean industrial sector won infrastructure projects in Vietnam and many other manufacturing opportunities at home (ibidem). Comprehensive economic planning allowed an increase in savings which grew at 8\% per year from 1965-1991 (ibidem). The South Korean model of earning demographic dividend may be well applied in Pakistan. Replicating the South Korean model would require effective population policies to slow the rate of population growth, women education, and timely changes in overall socioeconomic structures to enable the demographic dividend to yield its result.

Thailand would be another case study in this connection. Thailand has been able to reap the benefits of demographic dividend during last four decades. The Thai success is based on addressing the need of slowing the population growth rate by expanding family planning programs which helped decline the fertility rate from 5.5 children per women to 2.2 (Bremmer, Gribble, 2004). The Thai government realizing the potential of high growth rate in early 1960 s for earning demographic dividend. Investing in infrastructure in terms of transition from a rural based farming economy to industrialization had jumped started the economy. Building of roads and irrigation systems helped grow the size of economy by many folds (Four Steps, 2013). In the second stage the Thai government turned its focus to population planning policies. The two-fold population planning was to reduce fertility and create public awareness about family planning which also yielded positive results because of high literacy rate (ibidem).

\section{REAPING THE BENEFITS OF DEMOGRAPHIC DIVIDEND: CHALLENGES}

There are huge challenges ahead in setting things right for getting benefits of demographic dividend:

- In its seventh decade, the Pakistani population has increased from 34 million in 1951 to an estimated 171 million in 2009. It has increased five-fold since 1951. Slowing down the growth rate of an ever-increasing Pakistani population is definitely a big challenge. 
- The biggest challenge would be to reap the demographic dividend alongside planning to lower the current fertility rate because at current rate the expected population would be 450 million in 2050 and with current gradual drop in growth rate the population would be 350 million in 2050 .

- Another challenge is to aware Pakistani women of their right to know about choice of contraceptives. According to population studies $96 \%$ of Pakistani women are aware of at least one modern contraceptive but only $22 \%$ currently using it and $8 \%$ are using traditional methods. At least $25 \%$ of women want to give a gap of some years before giving birth but are not aware of effective use of contraceptives. $24 \%$ of women admit that their child was untimely or unplanned (Population policy, 2010).

- According to Demographic Health Survey 2006-7, 65\% Pakistani women had at least one abortion before the age of 30 .

- Another challenge is about semantics as population control is considered negative in Pakistan especially after the Abbotabad Operation in May 2011 by US Navy Seals to kill Al-Qaeda Emir Osama Bin Laden who was living in a compound in Abbotabad. Allegedly the US government (CIA per se) used non-governmental organizations such as Save the Children to collect DNA sample of Bin Laden family in the guise of polio workers. Many polio workers later lost their lives in targeted killings by Islamist militants in many parts of Pakistan. Even before this episode the orthodox clergy had launched a smear campaign to publicly discredit the population control campaign by making false accusations. To discredit such ideas the population policy now uses term 'birth spacing' of at least 36 months.

- Pakistan is one of the countries with lowest literacy rates in the world. With world literacy rate of $84 \%$, Pakistan lags far behind with $55 \%$. In such scenario it is more difficult to convince Pakistani masses for family planning.

- A major challenge for implementing the policy would be public service delivery issue. It would be much difficult to expand the network of service delivery especially with regard to birth spacing campaign from urban to rural areas.

- Without women literacy level all of the efforts would go in vain. The female literacy holds key in family planning, which in return help earn the demographic dividend. To increase the current abysmally low female (42\%) literacy rate may be a Herculean task to achieve.

\section{IMPACT OF DEMOGRAPHIC TRANSITION ON TERRORISM IN PAKISTAN}

There appears to be a tremendous impact of changing demographics of Pakistan and rising terrorism. Pakistan is somehow a unique case of demographic dividend as it is the only country hitherto which is experiencing demographic dividend and also passing through a difficult phase concerning the incidents of terrorism. Simply put, the country is also experiencing the phenomenon of terrorism. There are 212 proscribed terrorist organizations in Pakistan with some having quite a large number of members. With the presence of a plethora of terrorist organizations operating on Pakistani territory it appears that the benefits of demographic dividend could also be reaped by terrorist groups. One primary reason would 
be weak economic indicators which could help these organizations establish a parallel network of charity, relief, rescue, social services, education, health and religious seminaries. The consistent growth of population with little or no economic engagement would benefit terrorist organization already running an underground network.

Pakistan is one the worst victims of terrorism. More than 55,000 people have lost their lives during last 14 years of Islamist terrorist attacks. It would not be apt to say that the Pakistan's terrorism related problems started after the commencement of Global War on Terror (GWOT) in October 2001 in which the country is playing a pivotal role.

The dark side of the demographic explosion could be terrorism. There may be many other fallouts such as rise in crime, local feuds, civil war and other forms of political violence but fragile states with ungoverned territories, the demographic disproportions vis-à-vis resources may pave the way for terrorism. According to C Cohen: "Pakistan's population doubled between 1961 and 1982, a period of just 21 years. The United Nations (UN) projects that by 2050 Pakistan's population could double again to more than 350 million people, making it the world's third or fourth most populous country" (Cohen, 2008).

Pakistan ranked third in Global Terrorism Index and was one of the five countries constituting $82 \%$ of the people killed in terrorist attacks worldwide in 2013 (Global Terrorism Index, 2014). Out of five worst terrorist attacks as far as fatalities were concerned, three occurred in Pakistan. There was a 37\% increase in deaths resulting because of terrorist incidents, in 1933 terrorist attacks 2,345 people lost their lives and 5,035 received injuries, 23 major terrorist groups remained active in Pakistan in 2013 out of which 11 accounted for 270 terrorist attacks, 100 attacks on educational institutions, 71 suicide bombings causing 2,740 casualties, at least one terrorist attack recorded in 500 cities in Pakistan, at least two or more in 180 cities, and $16 \%$ all terrorist attacks occurred in the most populous city Karachi in 2013 (ibidem).

Table 2

Victims of terrorist attacks in Pakistan since 2003

\begin{tabular}{|c|c|c|c|r|}
\hline Rok & Civilians & $\begin{array}{c}\text { Security Force } \\
\text { Personnel }\end{array}$ & $\begin{array}{c}\text { Terrorists/ } \\
\text { Insurgents }\end{array}$ & Total \\
\hline 2003 & 140 & 24 & 25 & 189 \\
\hline 2004 & 435 & 184 & 244 & 863 \\
\hline 2005 & 430 & 81 & 137 & 648 \\
\hline 2006 & 608 & 325 & 538 & 1,471 \\
\hline 2007 & 1,522 & 597 & 1,479 & 3,598 \\
\hline 2008 & 2,155 & 654 & 3,906 & 6,715 \\
\hline 2009 & 2,324 & 991 & 8,389 & 11,704 \\
\hline 2010 & 1,796 & 469 & 5,170 & 7,435 \\
\hline 2011 & 2,738 & 765 & 2,800 & 6,303 \\
\hline 2012 & 3,007 & 732 & 2,472 & 6,211 \\
\hline 2013 & 3,001 & 676 & 1,702 & 5,379 \\
\hline 2014 & 1,781 & 533 & 3,182 & 5,496 \\
\hline 2015 & 853 & 305 & 2,217 & 3,376 \\
\hline Total & $\mathbf{2 0 , 7 9 0}$ & $\mathbf{6 , 3 3 6}$ & $\mathbf{3 2 , 2 6 1}$ & $\mathbf{5 9 , 3 8 8}$ \\
\hline
\end{tabular}

Source: South Asia Terrorism Portal, 2015 (data as of November 2015). 
The increasing number of suicide attacks in last 13 years is indicative of higher recruitment levels achieved by terrorist organizations, an advantage of population transition, and allowing terrorists to reap the benefits of demographic dividend.

Table 3

Results of terrorist attacks in Pakistan since 2003

\begin{tabular}{|c|c|c|c|}
\hline Year & Incidents & Killed & Injured \\
\hline 2003 & 2 & 69 & 103 \\
\hline 2004 & 7 & 89 & 321 \\
\hline 2005 & 4 & 84 & 219 \\
\hline 2006 & 7 & 161 & 352 \\
\hline 2007 & 54 & 765 & 1,677 \\
\hline 2008 & 59 & 893 & 1,846 \\
\hline 2009 & 76 & 949 & 2,356 \\
\hline 2010 & 49 & 1,167 & 2,199 \\
\hline 2011 & 41 & 628 & 1,183 \\
\hline 2012 & 39 & 365 & 607 \\
\hline 2013 & 43 & 751 & 1,411 \\
\hline 2014 & 25 & 336 & 601 \\
\hline 2015 & 19 & 161 & 360 \\
\hline Total & $\mathbf{4 2 6}$ & $\mathbf{6 , 4 3 3}$ & $\mathbf{1 3 , 2 6 9}$ \\
\hline
\end{tabular}

Source: South Asia Terrorism Portal.

Terrorism has a direct effect on Pakistani economy, which has suffered tremendously. According to the Economic Survey of Pakistan the economic losses because of terrorism stand at $\$ 107$ billion (Mukhtar, 2015). Unemployment and inflation rates are also increasing and the core inflation rate in Pakistan averaged 8.46\% from 2010 until 2015 (Pakistan Core Inflation, 2015).

Estimated Economic Losses 2001-15

\begin{tabular}{|c|c|}
\hline Fiscal Year & Losses in billions (\$) \\
\hline 1 & 2 \\
\hline $2001-2$ & 2.67 \\
\hline $2002-3$ & 2.75 \\
\hline $2003-4$ & 2.93 \\
\hline $2004-5$ & 3.41 \\
\hline $2005-6$ & 3.99 \\
\hline $2006-7$ & 4.67 \\
\hline $2007-8$ & 6.94 \\
\hline $2008-9$ & 9.18 \\
\hline $2009-10$ & 13.56 \\
\hline $2010-11$ & 23.77 \\
\hline
\end{tabular}




\begin{tabular}{|c|c|}
\hline 1 & 2 \\
\hline $2011-12$ & 11.98 \\
\hline $2012-13$ & 9.97 \\
\hline $2013-14$ & 6.63 \\
\hline $2014-15$ & 4.53 \\
\hline Total & $\mathbf{1 0 6 . 9 8}$ \\
\hline
\end{tabular}

Source: Pakistan Core Inflation Rate 2010-16 (2015), Trading Economics, http://www.tradingeconomics.com/pakistan/core-inflation-rate (12.01.2016).

It is almost impossible to find an exact number of terrorists active in Pakistan, though, one knows the number of terrorist organizations. ${ }^{2}$ There have been various estimates presented by expert, think tanks, and other sources. Table 5. presents principal terrorist organizations in Pakistan on the basis of their strength, affiliations with global terrorist organizations, and ideology and areas of operation.

Principal terrorist organizations in Pakistan

\begin{tabular}{|l|l|l|l||}
\hline $\begin{array}{c}\text { Pakistani } \\
\text { Islamist } \\
\text { terrorist } \\
\text { organizations }\end{array}$ & \multicolumn{1}{|c|}{ Ideology } & Stated Aims and Goals & \multicolumn{1}{||}{ Remarks } \\
\hline HuJI & Deobandi & $\begin{array}{l}\text { Kashmir, Caliphate, Sharia, } \\
\text { Anti-American/Western }\end{array}$ & Allied with Al-Qaeda \\
\hline HuM & Deobandi & $\begin{array}{l}\text { Kashmir, Caliphate and, Sharia } \\
\text { in Pakistan }\end{array}$ & Allied with Al-Qaeda \\
\hline LeJ & Deobandi & $\begin{array}{l}\text { Anti-Shia, Anti-Sufi sects, } \\
\text { anti-American/Western }\end{array}$ & Allied with Al-Qaeda \\
\hline JeM & Deobandi & $\begin{array}{l}\text { Indian Kashmir, Caliphate and } \\
\text { Sharia in Pakistan }\end{array}$ & Allied with Al-Qaeda \\
\hline LeT & Wahabi/Salafist & $\begin{array}{l}\text { Insurgency in Indian Kashmir, } \\
\text { Caliphate and Sharia in Paki- } \\
\text { stan, Regional and global am- } \\
\text { bitions }\end{array}$ & $\begin{array}{l}\text { Discreetly allied with Al-Qaeda and its } \\
\text { splinter factions fighting in Kunar against } \\
\text { US Forces, still not overtly anti-Pakistan } \\
\text { but in collusion with Islamist groups }\end{array}$ \\
\hline TTP & $\begin{array}{l}\text { Deobandi-Wahabi/ } \\
\text { Salafist }\end{array}$ & $\begin{array}{l}\text { Turning Pakistan into Caliph- } \\
\text { ate, Sharia law, defeating Pa- } \\
\text { kistani security forces, driving } \\
\text { Pakistani forces out of tribal } \\
\text { areas }\end{array}$ & $\begin{array}{l}\text { Main collaborator of Al-Qaeda Central } \\
\text { based in Pakistani tribal areas and also } \\
\text { provided safe havens to Pakistani Islamist } \\
\text { groups and international Islamists such } \\
\text { as IMU/IJ, LIFG, ETIM etc. }\end{array}$ \\
\hline \hline
\end{tabular}

According to several estimates the current strength of terrorist organizations in $\mathrm{Pa}$ kistan is in thousands. International think-tanks and research organizations have at-

2 According to Ministry of Interior's list of proscribed organizations, the number currently stands at 60 whereas the Ministry of Foreign Affairs maintains its separate list of 171 terrorist organizations. 
tempted to calculate the figure, such as South Asia Terrorism Portal (SATP), Federation of American Scientists (FAS), and US Department of State (Tab. 6).

Table 6

The current strength of principal terrorist organizations in Pakistan

\begin{tabular}{||l|c|c|c||}
\hline Organization & $\begin{array}{c}\text { Strength according } \\
\text { to South Asia Terrorism } \\
\text { Portal Data }\end{array}$ & $\begin{array}{c}\text { Strength according } \\
\text { to Global Terrorism } \\
\text { Database, START }\end{array}$ & $\begin{array}{c}\text { Strength according to } \\
\text { US Department of State }\end{array}$ \\
\hline HuJ & $500-700$ & Not known & $300-500$ \\
\hline HuM & 1,000 & 300 & $300-500$ \\
\hline LeJ & 300 & 300 & 500 \\
\hline LeT & 750 & 300 & $2,000-3,000$ \\
\hline JeM & 500 & 100 & $300-500$ \\
\hline TTP & $30,000-35,000$ & - & $2,000-3,000$ \\
\hline
\end{tabular}

Source: South Asia Terrorism Portal (SATP), Global Terrorism Database (START), University of Maryland, and Country Reports on Terrorism, 2011, US State Department's Foreign Terrorist Organizations.

Islamist terrorist organizations in Pakistan appear to be in a position to capitalize on demographic transition. Therefore it is pertinent to discuss principal Islamist terrorist organizations operating in Pakistan.

\section{A. Harkat ul Jihad Islami (HuJI)}

$\mathrm{HuJ}$ is a jihadist/militant Islamist violent non-state actor born out of Afghan War. Its exact year of coming into being is not known but considered to be 1983 when it started jihadi activities in Afghanistan alongside Afghan Islamist Mujahedeen groups. HuJI was in fact the first Islamist armed non-state actor founded in Pakistan during Afghan War. It's truly the founding stone moving towards formation of Islamist terrorist organizations. HuJ changed its jihadist front from Afghanistan to Kashmir in 1989. It had become international with opening up of branches in India, Myanmar and Bangladesh. ${ }^{3}$ HuJ's adheres to Deobandi/Wahabi radical school of thought and since its inception it has successfully drawn recruits from Deobandi madrasahs managed by Islamist political party JUI. ${ }^{4}$ It is hybrid in a sense that many of its followers are Punjabis and Pashtuns. HuJI has played a key role in providing militant leadership to later radical Islamist groups belonging to same radical school of thought. The leadership of most of the radical Islamists terrorist organizations in Pakistan, previously belonged to HuJI. Therefore we could say that all started from HuJI. The radical mindset, ideology, training camps, tactics, guerrilla war experience, jihadi spirit, madrasah recruitment; leaders from both Punjabis and Pashtun ethnic groups, pan-Islamist radical agendas etc are all today's critical issues that sprang from the fountain of HuЛ.

3 Interview with Imtiaz Gul, security expert and Islamabad-based journalist.

4 Interview with Mujahid Hussain, security expert and Belgium-based Pakistani journalist. 
HuJI was founded by Maulana Irshad Ahmad and his trusted lieutenants Qari Saifullah Akhter, and Fazalur Rehman Khalil. Irshad Ahmad was a Punjabi whereas Akhter and Khalil were Pashtuns from Khyber-Pakhtunkhawa province of Pakistan. All of them had graduated from Deobandi seminary Banori Town in Karachi. HuJ is simultaneously Afghan jihadist, Kashmiri, sectarian, pro-Taliban, pro-Al-Qaeda, and anti-western and anti-American. Thus, implying the point made earlier in this chapter about the characteristics of such kind of Islamist-deobandist-wahabist violent non-state actors. HuJ has been able to conduct 19 terrorist attacks since 2001 in Pakistan in collusion with Al-Qaeda Central based in Pakistan's tribal areas (Global Terrorism Database, 2012).

\section{B. Harkatul Mujahedeen (HuM)}

Harkatul Mujahedeen (HuM) is a break-away faction of Harkatul Jihad Islami (HuJ). The HuM was established by former HuJI leader Fazal-ur-Rehman Khalil in 1989, even then Khalil maintained its relations with HuJI, the parent party. HuM restricted its jihadist activities to Kashmir insurgency up till 1998 and the focus remained anti-India. HuM's global ambitions came to surface in February 1998 when HuM's Amir Khalil signed a declaration of war, the establishment of Islamic Front against Jews and Crusaders against the US and its allies coupled with religious edict the Fatwa against Jews and Crusaders alongside Bin Laden in Afghanistan (Compilation, 2004).

HuM is closely allied with Al-Qaeda Central. Not to mention the HuM chief Fazalur Rehman Khalil signing the 1998 Fatwa against the US alongside Osama Bin Laden, from the platform of Islamic Front against Jews and Crusaders (Jihad against, 1998).

More than $20 \mathrm{HuM}$ rank and files killed when US cruise missiles hit Al-Qaeda-run training camp in Khost in 1998 where they were receiving training. The Tomahawk Cruise missiles were fired by the US Navy in reaction to East African US Embassies' bombings by Al-Qaeda in 1998 (Operation, 1998). HuM and its offshoot HuM al-Alami have been responsible for 13 terrorist attacks since 2001, including assassination attempts against former President Pervez Musharraf (Harktat, 2006).

Material evidence retrieved during Operation Neptune Spear further established close links between Al-Qaeda and HuM. The US Navy Seal Team's raid at Bin Laden hideout in Abbotabad, Pakistan revealed that Bin Laden was in close contact with HuM leader Fazalur Rehman Khalil and it has been speculated that the safe house was provided to Bin Laden through his HuM connections. HuM's leaders had to go underground and its rank and file had to seize their jihadi activities or join other Jihadi outfits after the Pakistani state reacted strongly to HuM's involvement in the murder of Daniel Pearl's kidnapping and assassination in collusion with A1-Qaeda in 2002 in Karachi. Aźbigger event was HuM's involvement in two attempted assassination of then Pakistani President and Chief of Army Staff General Pervez Musharaff in 2003 in Rawalpindi. 


\section{Lashkar-e-Jhangvi}

Lashkar-e-Jhangvi (LeJ) is a Punjab-based extremist anti-Shia sect group. The Islamist terrorist group adheres to radical Deobandi sect ideology. The LeJ is considered to be a break-away faction of its parent sectarian organization Sipah-e-Sihaba (army of the Companions). Siphah-e-Sihaba was formed in the aftermath of growing Shia opposition to General Zia's Islamization policies (1980-88). Zia regime's Islamist policies had effected religious beliefs of Shia-Muslims and they strongly protested against his policies. The military dictator's policy of collecting alms money annoyed Pakistani Shias and they staged a sit-in forcing the military regime to roll back the decision for Shias. General Zia, in an attempt to teach Shias a lesson, used his intelligence apparatus to support anti-Shia Islamist militant groups, prominent amongst them was Sipah-e-Sahaba (Army of the Companions), the parent party of LeJ. The LeJ was born out of that hostile scenario and used brutal violent force against Pakistani Shias and their leadership. ${ }^{5}$

\section{Jaish-e-Mohammad}

Jaish-e-Mohammad (JeM) is a semi-urban jihadist-sectarian organization; originally came into being during Islamist insurgency in Indian Kashmir (1989-2002). The JeM surfaced during the Kashmir insurgency by 2000. JeM was established by Masood Azhar, a graduate of Dar ul Uloom Islamia madrasah located at Binori Town, Karachi. Azhar joined Harkatul Jihad ul Islami (HuJI) in 1983 and later climbed up to become the secretary general of Harkatul Mujahedeen (HuM) after the HuM parted ways with HuJI in 1987.

Azhar parted ways with HuM after his release from Indian custody and laid the foundations of Jaish-e-Mohammad in late 2000. Initially JeM drew most of its membership from the like-minded Deobandi jihadi groups such HuM, Sipah-e-Sihaba and its militant faction Lashkar-e-Jhangvi and HuJI. It is widely believed that JeM was created by elements of Islamist network in Pakistan and state security apparatus to increase competition amongst jihadi outfits. ${ }^{6}$

For many experts and analysts Islamist violent non-state actors like JeM, LJ/SeS, HuM, and HuJ, with their urban nature and because of their non-Pashtun membership

5 During the early days of Afghan War, camps were established in Pakistani tribal areas for Afghan refugees, side-by-side training camps were also established. Those refugee camps provided manpower and therefore were key for CIA-ISI recruitment drive. In Kurram district of Pakistani tribal areas, where Shias constituted majority the demographic balance was getting upset because of large number of Afghan-Pashtuns migrated to that districts because of Afghan War. The result was armed hostilities and fighting, and death of hundreds from both sides. General Zia and ISI also supported Sunnis and Afghan Pashtuns to crush growing disobedience of Shias. During mid-1980s the government-Shia community rivalry had touched new levels and even Zia's mysterious death in plane crash was also allegedly blamed by some on his Shia pilot.

${ }^{6}$ Interview with Zahid Hussain, Pakistani journalist and academic and author of two books on Pakistani jihadist groups. 
could broadly be defined as Punjabi Taliban. These groups are based in Punjab and mostly operate in central and southern districts of Punjab province with strong connections to tribal area Pashtun-Pakistani Taliban (Riikonen, 2010).

JeM developed its relationship with Al-Qaeda during Taliban period. JeM was formed with blessings from Deobandi scholar Mufti Nizamud Din Shamzai, head cleric of Binori Town Mosque/madressah (aka Dar ulUloomIslamiaBinori Town) at Karachi. Shamzai had longstanding ties with A1-Qaeda and Taliban. Shamzai also had played pivotal role in the formation of HuJI, HuM and LeJ, and many Taliban high command leaders studied at his seminary (Mufti, 2004). In fact Shamzai used his influence over all Deoabndi-Wahabi outfits and Islamist parties to develop ties. Right after JeM's formation in 2000 the Taliban allowed nascent organization's rank and files to receive training at $\mathrm{Al}$-Qaeda-run training camps in Afghanistan. JeM fostered close relations with Al-Qaeda from the beginning and with the commencement of GWOT reciprocated by launching attack at Indian Parliament on December 13, 2001 (Indian parliament, 2003). The terrorist operation had resulted in an India-Pakistan military standoff, and provided a breathing space to Al-Qaeda leaders besieged in tribal areas by Pakistani security forces. Kidnapping and murder of Wall Street Journal's correspondent Daniel Pearl was an Al-Qaeda-JeM joint operation. Khalid Shaikh Mohammad, chief planner of 9/11 attacks was part of the venture. Khalid Shaikh after his arrest in 2003 from Rawalpindi revealed to his interrogators that he personally slit the throat of Pearl (Khalid, 2004). JeM even after splintering into several factions does have a potential to strike back.

\section{E. Lashkar-e-Taiba}

Lashkar-e-Taiba (LeT) is considered to be most lethal, highly organized and disciplined Islamist violent non-state actor in Pakistan. LeT has its roots in Afghan War. It was a late entrant into the conflict (during last days), inevitably had no significant role to play. LeT was established by Abdullah Yousaf Azzam who is also considered as co-founder of Al-Qaeda and its principal ideologue. Two former members of Islamist political party Jamaat-e-Islami (JI), also professors of Islamic Studies at University of Engineering and Technology, Lahore, Professor Zafar Iqbal and Professor Hafiz Saeed presented the idea to Abdullah Azzam of creating a separate militant Islamist organization purely on Wahabi/Salafist lines rather than working alongside Deobandi Islamist groups such as Harkatul Jihad Islami (HuJ) and Harkatul Mujahedeen (HuM). ${ }^{7}$

\footnotetext{
7 South Asian version of Wahabism is called Ahl-e-Hadith. The adherents of Ahl-e-Hadith don't prefer to call themselves Wahabist because of its negative connotations and hatred amongst other Sunni and Shia groups because of the destruction of Muslim holy sites in Mecca and Medina by Saudi-Wahabis. Furthermore in South Asia the Islam in practice by an overwhelming number of Muslims is either Sufi-Sunni or Shia Islam. The Ahl-e-Hadiths in Pakistan and India have always been supported by Saudis, Kuwaitis and other Arab Wahabi governments. JI is not an Ahl-e-Hadith party but has members from both Ahl-e-Hadith and Deobandi schools of thoughts, since it also espouses to the same radical interpretations but prefer to pronounce itself as pan-Islamist.
} 
The LeT and its founding members wanted to play a bigger role in Afghan War, but indeed they were latecomers. The Afghan War was about to end as Soviets had already signed the Geneva Accords in 1988 and last of their troops withdrew from Afghanistan in early 1989. LeT began its jihadi activities in Indian Kashmir Insurgency by early 1990s. LeT has a track record of spectacular attacks against Indian forces not only in Kashmir but also in mainland India. On two occasions LeT actions have brought India and Pakistan at the brink of full scale wars (Tanke1, 2010: 4). LeT's attack at Indian parliament on December, 2001 and seven years later on November 26, 2008 in Mumbai had produced severe repercussions and LeT actions stalled the peace talks between India and Pakistan and a situation disastrous for GWOT (Magnier, Sharma, 2008).

The LeT attack on Indian parliament was an ample proof of its support to Taliban and Al-Qaeda that had been under siege during Pakistan army operations against the run-away elements of these two entities. The amassing of Indian troops at Pakistan's eastern borders had pushed Pakistan to shift its forces from western to eastern borders. Those forces were engaging Al-Qaeda and Taliban remnants and therefore their westward shifting gave Islamist militants breathing space.

Arrest of LeT activist Ajmal Kasab during Mumbai attacks brought LeT into world focus. More than 183 citizens belonging to 27 countries lost their lives in Mumbai attacks in 2008 (Global Terrorism Database. Terrorist Attacks, 2012). Pakistani authorities blamed non-state actors for executing those attacks and offered cooperation for investigations. Arrest of another LeT activist involved in Mumbai attacks was Dawood Gillani (aka David Headly) arrested in the US. Gillani was charged for providing logistical assistance to LeT planners Zakiur Rehman Lakhvi and others for Mumbai attacks (Tankel, 2010: 5).

\section{F. Tehreek-e-Taliban Pakistan (TTP)}

Tehreek-e-Taliban Pakistan (TTP), though, a newcomer at Pakistani jihadist scene has become the lynchpin of all Islamist violent non-state actors. The TTP though an agglomerate of more than 40 Islamist tribal factions, is in true sense a violent non-state actor that could be compared with internationally known large-scale terrorist groups such as Colombian FARC, Lebanese Hezbollah, Northern Ireland's IRA, and Sri Lankan LTTE. Established in August 2007, the TTP was from the beginning closely linked to Al-Qaeda.

TTP is not monolithic. It is in fact a loose alliance of factions comprising of tribesmen of many different tribes having a long standing relationship with Al-Qaeda's leadership and had remained part of jihad during 1980s. The several different factions now part of TTP took some time in joining hands together. The alliance came to fruition after the initiation of Pakistani military operation against Wazir and Mehsud tribes supporting and sheltering A1-Qaeda and Afghan Taliban remnants fleeing Afghanistan after the US invasion. Therefore the TTP formally came into being in August 2007; the group existed before that without any formal and institutionalized set up. The influence of TTP could be ascertained from the peace deals the authorities had to sign with this tribal militia (Shakia Accord, Wana Accord, Sara Rogha and Mir Ali) (see: Rana Sial, Basit, 2010). 
Most of the 425 suicide attacks in Pakistan from 2002 to present were claimed by TTP and its affiliated groups (the Punjabi Islamist groups). The TTP has A1-Qaeda expertise on its side. It is the most significant overt threat to the security of Pakistan (Mir, 2011). The TTP is considered the most-allied ally of Al-Qaeda in Pakistan. It is because of TTP that other five principal Islamist terrorist organizations HuM, HuJ, JeM, LeJ and LeT have been able to target Pakistani cities and military installations. It is observed that during most of the suicide attacks in Pakistan most of the suicide bombers were provided by TTP to other five organizations (HuJ, HuM, LeJ, LeT and JeM), and the organization had facilitated the suicide operations. Many of the suicide attacks and bombings including high profile cases such as assassination attempts on President Pervez Musharraf in 2002 and 2003, Prime Minister Shaukat Aziz in 2004, Marriot Hotel bombing in 2008; were even planned by Al-Qaeda operatives such as Abu Faraj al Libi based in tribal areas in collusion with TTP.

\section{LIKNING DEMOGRAPHIC DIVIDEND TO TERRORISM}

Demographic dividend is a phenomenon whereas terrorism is a tactic as well as an intriguing phenomenon. Terrorist organization act as 'shadow armies', and consider themselves 'shadow states'. The substantial growth of terrorism in Pakistan has weakened the foundations of the state as the country has lost suffered $\$ 100$ bn losses in last 15 years. Currently Pakistan ranks $13^{\text {th }}$ in Fragile State Index and $5^{\text {th }}$ in Global Terrorism Index by virtue of terrorist activity in the country. With millions of youth joining the workforce with no skills the country would plunge into a serious problem as the unemployment rate would continue to rise amid a weak economic growth rate. The terrorist organization with their thriving network may be able to capitalize on it. For example, Pakistan's most powerful Islamist terrorist organization Lashkar-e-Taiba (LeT) would find more easily accessible recruits and if currently it is having an estimated strength of $2000-3000$ then it would surge to 4500 in 2025 (w.r.t population size) and same would happen with others such as TTP. The TTP's current estimated strength is $30,000-35,000$ which would grow up to 45,000 to 50,000 in 2025 as per the current expected population growth rate. The figure may rise exponentially as the unemployment rates would also rise with the population growth keeping in view of no major employment opportunities in the country. Keeping the current indicator constant such as growth rate, population growth rate, rising income gaps, swelling membership of terrorist organization, weak governance, and presence of ungoverned territories this situation would perhaps aggravate an direct relation between youth bulge and the size of terrorist organizations.

\section{DEVISING A STRATEGY FOR COUNTERING TERRORISM AMID POPULATION TRANSITION}

The apparent scenarios may be of three types that could result from taking advantage of the upcoming situation and/or letting it go: 
- Millions more are going to enter the job market in next 5-10 years. The abundance of such large labor force may act as an indicator of economic development or create humongous problems for any government. The current scenario may allow terrorist organizations specially the Islamist ones to recruit more easily and conveniently;

- If such large labor force becomes engaged with Islamist terrorist groups it may unleash an unprecedented wave of terrorism;

- The current dilapidated education system in Pakistan requires immediate improvements and if not the situation would get worsened to a point-of-no-return and an unskilled and uneducated population in millions may become very difficult to handle. A sharp increase in crime and also terrorism could be some of the expected outcomes as more and more pupils either remain without schooling or join religious seminaries. Though not all religious seminaries produce terrorists but even a small number graduating from these seminaries could be in hundreds of thousands as the total number of graduates would be in millions.

Pakistan needs to throw its weight behind demographic dividend. The once-in-a-life time opportunity must not be lost to flawed policies. Pakistan's demographic dividend started in 1990 and the window of opportunity is expected to close by 2050 , hence, $\mathrm{Pa}$ kistan still has 35 more years to reap, despite already losing 25 . The strategy to reap the benefits of demographic dividend may be devised at federal level under Finance Division with provincial population departments on board. The three-pronged strategy may be comprised of:

1) increasing the enrolment rate;

2) establishing more technical colleges with a sound strategy paper from center;

3) female education and equal employment opportunities.

There are ways to tackle the situation but requires concerted efforts of federal, provincial governments, bureaucracy, and opinion leaders especially from key media personalities who can influence public opinion. The National Population Policy 2010 must be revised and synchronized with National Education Policy.

Currently the primary school enrolment rate in Pakistan stands at $72 \%$ according to the World Bank figures. The gap is of $28 \%$ which needs to be filled in next five years. Even countries like Saudi Arabia 97\%, Papua New Guinea 86\%, Mongolia 95\%, and Ghana 95\% have been able to enrol most of their school going children (School, 2015).

Juxtaposing to increasing the enrolment rate if the government wants to reap demographic dividend then it would need to open more technical and vocational training colleges on immediate basis. With more colleges there would be a need to hire more teachers and that would create job opportunities for qualified graduates who are planning to leave the country for better employment options in the Gulf or Western Europe. For earning demographic dividend the focus must be on raising a formally skilled labor force as the unskilled force may turn the dividend into a disaster rather a demographic threat.

The government needs to invest in female education if it wants to maximize the demographic dividend. More women at home without any education would harm doubly. Firstly the fertility rate would continue growing and keep the resources at a breakeven levels, and secondly that no or under-utilization of more than $50 \%$ of workforce would minimize the offered benefits of demographic dividend. 
Therefore, we may suggest that reaping the demographic dividend is still possible even after losing first 25 years right after its advent in Pakistan. The next 35 years may yield positive result for boasting Pakistan's sluggish economy but consistent, systematic and organized efforts are required at federal government level.

*** *

Demographic dividend is a gift of nature which provides the beneficiary state an opportunity to accelerate its economic growth for attaining a high level of infrastructural and economic development in a short period of time. The benefits of demographic dividend may not be achieved until the host country starts taking steps in lowering the fertility rate, child mortality rate and address the educational and health related needs of their young population. The need as one could see from experienced nations' example in prioritizing the key areas and devising a strategy in order to reap the benefits in material sense.

Pakistan has hitherto not ready to earn the benefits of demographic dividend. It is expected that 60 million more people will be added in next 15 years and in next 20 years 110 million work-force would be added in the job market. On one hand it may be highly advantageous for the economy to grow at a rapid rate if the government manages to create meet the supply-demand curve with job market equilibrium. On other hand if the situation is not handled it may turn out to be disaster as with such big number of unemployed people on the streets. In next 10 years the urban population of Pakistan would constitute $50 \%$ of the total population. This would be an ideal situation terrorist recruitment and size of terrorist organizations would also increase vis-r-vis the population growth. The Islamist terrorist organizations would capitalize on this upcoming situation as they have the required trained cadres and infrastructure to reap the benefits of the demographic dividend. In case the country fails to reap the benefits of demographic dividend then the terrorist organizations would.

Despite having a flipside of demographic explosion, there is still some time left to set things right in Pakistan. Pakistan needs to increase its primary enrollment, female literacy level, and there is a dire need of more technical and vocational centers for churning out more professional and technical graduates required for attaining advantages of demographic dividend. Apart from these simultaneous efforts the government needs to embark upon devising a strategy if it is interested in reaping the benefits of the dividend. Macroeconomic matters of such magnitude require government intervention as no private sector or non-governmental initiative could suffice the needs in changing times.

\section{BIBLIOGRAPHY}

Aiyar S., Mody A. (2011), The Demographic Dividend: Evidence from the Indian States, "IMF Working Paper Series", WP/11/38, International Monetary Fund, http://www.imf.org/exter$\mathrm{nal} / \mathrm{pubs} / \mathrm{ft} / \mathrm{wp} / 2011 / \mathrm{wp} 1138 . p d f$ (22.09.2015).

Amjad R. (2013), Why has Pakistan not Reaped its Demographic Dividend?, in: Capturing the Demographic Dividend in Pakistan, Population Council. 
Bloom D. E., Canning D. (2004), Global demographic change: Dimensions and economic significance, "NBER Working Paper", No. 10817, Washington.

Bloom D. E., Williamson J. G. (1998), Demographic transitions and economic miracles in emerging Asia, "The World Bank Economic Review", Vol. 12, No. 3.

Bokhari S. R. (2011), Demographic Dividend - Opportunity or Threat, "Express Tribune", 17.10.2011.

Bremmer J., Gribble J. (2004), The Challenge of attaining the demographic dividend, "Policy Brief: Population Reference Bureau", http://www.prb.org/pdf12/demographic-dividend.pdf (22.09.2015)

Burki S. J. (2011), Historical Trends in Pakistan's Demographics and Population Policy, in: Reaping the Dividend Overcoming Pakistan's Demographic Challenges, (eds.) M. Kugelman, R. M. Hathaway, Washington DC.

Can Pakistan Reap Its Demographic Dividend? (2012), US AID, Research and Development Solutions, Policy Brief Series, No. 16.

Capturing the Demographic Dividend in Pakistan (2013), (eds.) Z. A. Sathar, R. Royan, J. Bongaarts. Islamabad.

Cohen C. (2008), Pakistan 2020: The Policy Imperatives of Pakistani Demographics, Nonproliferation Policy Education Centre, Arlington.

Compilation of Usama Bin Ladin Statements 1994-January 2004 (2004), FBIS Report, US Foreign Broadcast Information Service.

Demographic Dividend (2008), United Nations Population Fund, http://www.unfpa.org/demographic-dividend (1.09.2015).

Durr-e-Nayyab (2008), Demographic Dividend or Demographic Threat in Pakistan?, "The Pakistan Development Review", Vol. 47, No. 1.

Four Steps to Thailand's Demographic Dividend (2013), "News Security Beat Wilson Center". 4.04.2013, http://www.newsecuritybeat.org/2013/04/steps-thailands-demographic-dividend/ (21.09.2015).

GDP Growth (annual \%) (2015), World Bank Data, http://data.worldbank.org/indicator/NY.GDP. MKTP.KD.ZG (22.09.2015).

Global Terrorism Database [HuJI] (2012), National Consortium for the Study of Terrorism and Responses to Terrorism (START), http://www.start.umd.edu/gtd (5.01.2016).

Global Terrorism Database. Terrorist Attacks in India (2012), National Consortium for the Study of Terrorism and Responses to Terrorism (START), http://www.start.umd.edu/gtd (12.01.2016).

Global Terrorism Index 2014 (2014), Institute of Economics and Peace, http://www.visionofhumanity.org/sites/default/files/Global\%20Terrorism\%20Index\%20Report\%202014_0.pdf (12.01.2016).

Gribble J. N. (2012), South Korea's Demographic Dividend, Population Reference Bureau, November 2012, http://www.prb.org/Publications/Articles/2012/south-korea-population.aspx (22.09.2015).

Harktat-ulMujahideen al-Alami (2006), South Asia Terrorism Portal (SATP), http://www.satp.org/ satporgtp/countries/pakistan/terroristoutfits/HuMA.htm (12.01.2016).

Indian parliament attack: court upholds death for two Kashmiris, "Daily Times", 30.10.2003, $\mathrm{http}: / /$ www.dailytimes.com.pk/default.asp?page=story_30-10-2003_pg7_9 (12.01.2016).

Jihad against Jews and Crusaders: World Islamic Front Statement (2004), Text of Bin Laden's Fatwa against the US, http://www.fas.org/irp/world/para/docs/980223-fatwa.htm (12.01.2016).

Khalid Sheikh slit Pearl's throat: FBI, "Daily Times", 20.12.2004, http://www.dailytimes.com.pk/default.asp?page=-story_20-12-2004_pg1_4 (12.01.2016). 
Kugelman M. (2011), Pakistan's Demographics: Possibilities, Perils, and Prescriptions, in: Reaping the Dividend Overcoming Pakistan's Demographic Challenges, (eds.) M. Kugelman, R. M. Hathaway, Washington.

Magnier M., Sharma S. (2008), Terror Attacks Ravage Mumbai: At Least 101 Die; Americans, Britons Apparently Sought as Hostages, "Los Angeles Times", 27.11.2008, http:/articles.latimes.com/ print/2008/nov/27/world/fg-mumbai27 (12.01.2016).

Mir A. (2011), Ten Years after 9/11: suicide attacks declining in Pakistan, "The News, Islamabad", 12.09.2011.

Mukhtar I. (2015), Pakistan suffered $\$ 107$ b loss due to terror war, "Nation", 5.06.2015, http://nation.com.pk/islamabad/05-Jun-2015/pakistan-suffered-107b-loss-due-to-terror-war (12.01.2016).

Mufti Shamzai-a profile (2004), "Daily Times", 31.05.2004, http://www.dailytimes.com.pk/default.asp?page=-story_31-5-2004_pg7_24 (12.01.2016).

Nayab D. (2008), Demographic Dividend or Demographic Threat in Pakistan, "The Pakistan Development Review", Vol. 47, No. 1.

Nagarajan R. (2014), Without jobs, India's demographic dividend will be a disaster: Alakh N Sharma, "Times of India", 12.02.2014, http://timesofindia.indiatimes.com/interviews/Without-jobsIndias-demographic-dividend-will-be-a-disaster-Alakh-N-Sharma/articleshow/30233665.cms (22.09.2015).

National Education Policy 2009 (2009), Ministry of Education, 1.08.2009, http://unesco.org.pk/education/teachereducation/files/National\%20Education\%20Policy.pdf (24.09.2015).

National Education Policy 2009 (2009), Ministry of Federal Education and Professional Training, http://moent.gov.pk/gop/index.php?q=aHR0cDovLzE5Mi4xNjguNzAuMTM2L21vcHR0bS91 c2VyZmlsZXMxL2ZpbGUvTmF0aW9uYWwlMjBFZHVjYXRpb24lMjBQb2xpY3kucGRm (2.09.2015).

Operation Infinite Reach (1998), Global Security, 20.08.1998, http://www.globalsecurity.org/military/ops/infinite-reach.htm (12.01.2016).

Pakistan Core Inflation Rate 2010-16 (2015), Trading Economics, http://www.tradingeconomics.com/ pakistan/core-inflation-rate (12.01.2016).

Pakistan Demographic and Health Survey 2012-13 (2013), National Institute of Population Studies, Islamabad.

Pakistan Economic Survey of Pakistan 2011-12 (2012), Ministry of Finance, Islamabad.

Pakistan's external debts, liabilities cross $\$ 65$ bn (2014), "Daily Times", 6.09.2014, http://www.dailytimes.com.pk/business/06-Sep-2014/pakistan-s-external-debts-liabilities-cross-65bn (25.11.2015).

Population policy: will it work? (2010), "Dawn", 14.03.2010, http://www.dawn.com/news/833074/ population-policy-will-it-work (22.09.2015).

Projected Populations 1950, 2000, 2015, 2025, 2050 (2012), http://www.photius.com/rankings/ world2050_rank.html (20.09.2015).

Rana M. A., Sial S., Basit A. (2010), Dynamics of Taliban Insurgency in FATA, Pakistani Institute of Peace Studies, Islamabad.

Reaping India's promised demographic dividend - Industry in Driving Seat (2010), Earnest and Young, India, http:/www.ey.com/Publication/vwLUAssets/EY-Government-and-Public-SectorReaping-Indias-demographic-dividend/\$FILE/EY-Reaping-Indias-promised-demographicdividend-industry-in-driving-seat.pdf (23.09.2015).

Riikonen K. (2010), Punjabi Taliban and the Sectarian Groups in Pakistan, "Pakistan Security and Research Unit", Brief No. 55.

Roser M. (n.d.), World Population Growth, OurWorldInData.org, http://ourworldindata.org/data/population-growth-vital-statistics/world-population-growth/ (25.09.2015). 
Schmid A. P. (2012), The Revised Academic Consensus Definition of Terrorism, "Perspectives on Terrorism", Vol. 6, No. 2.

School enrollment, primary (\%net) (2015), World Bank Data, http://data.worldbank.org/indicator/SE.PRM.NENR (22.09.2015).

Skills for Growth \& Development: A Draft National Technical and Vocational Education and Training (TVET) Policy. Consultation Document (2014), Ministry of Federal Education and Professional Training, http://moent.gov.pk/gop/index.php?q=aHR0cDovLzE5Mi4xNjguNzAu MTM2L21vcHR0bS91c2VyZmlsZXMxL2ZpbGUvRmluYWwlMjBDb25zdWx0JTIwUGF wZXIIMjBvZiUyMFRFV1QIMjBQb2xpY3kucGRm (2.09.2015).

Tankel S. (2010), Lashkar-e-Taiba in Perspective: An Evolving Threat, New America Foundation, $\mathrm{http}: /$ www.newamerica.net/sites/newamerica.net/files/policydocs/tankel.pdf (12.01.2016).

Tharoor Sh. (2014), We Are Growing Younger; China, Others are Ageing. Advantage India, NDTV, 24.09.2014, http://www.ndtv.com/opinion/we-are-growing-younger-china-others-are-ageingadvantage-india-670552 (23.09.2015).

The N-11: More Than an Acronym (2007), Goldman Sachs Study of N-11 nations, "Global Economics Paper", No. 153, 28.03.2007.

World Economic Outlook. Semi-annual Report (2004), The IMF on Policies Responding to Demographic Change, Washington.

World Population Prospects: Key findings and advance tables (2015), UN Department of Economic and Social Welfare, Population Division, New York, http://esa.un.org/unpd/wpp/publications/files/key_findings_wpp_2015.pdf (12.01.2016).

\begin{abstract}
Demographic dividend could be considered as a corollary to demographic transition. Because of the shift in demographics with respect to mean age over a period of time more people fall under the age bracket of 15-64 than below 15 and above 64. Fortunately, Pakistan is considered to be one of these states experiencing the phenomenon of demographic dividend. Pakistan is also one the worst victims of terrorism, which can be regarded as the dark side of the demographic explosion. There may be many other fallouts such as rise in crime, local feuds, civil war and other forms of political violence but in fragile states with ungoverned territories, the demographic disproportions vis-ŕ-vis resources may pave the way for terrorism. This would be an ideal situation terrorist recruitment and size of terrorist organizations would also increase vis-r-vis the population growth. The Islamist terrorist organizations would capitalize on this upcoming situation as they have the required trained cadres and infrastructure to reap the benefits of the demographic dividend. In case the country fails to reap the benefits of demographic dividend then the terrorist organizations would.
\end{abstract}

Key words: Demographic dividend, Pakistan, terrorism

\title{
TERRORYZM - MROCZNA STRONA DYWIDENDY DEMOGRAFICZNEJ NA PRZYKLADZIE PAKISTANU
}

\section{STRESZCZENIE}

Pakistan postrzegany jest jako jedno z tych państw, które w największym stopniu doświadcza dywidendy demograficznej. Jest także swoistą ofiarą terroryzmu, który stanowi "ciemną 
stronę" eksplozji demograficznej. Mogą pojawić się oczywiście inne negatywne zjawiska, takie jak wzrost przestępczości, korupcja, konflikty wewnętrzne i inne formy przemocy politycznej, lecz w państwach kruchych dysproporcje demograficzne mogą nasilić zjawisko terroryzmu.

Slowa kluczowe: Pakistan, dywidenda demograficzna, terroryzm 